\title{
Current challenges for sustainable forestry management in Ukraine: production, taxation and investments issues
}

\author{
Orest Furdychko*, Okesana Drebot**, Oleg Yaremko ${ }^{* * *}$, Volodymyr Bondar ${ }^{* * *}$, Mariya \\ Vysochansk. ${ }^{* * * * *}$, Lyudmila Sakharnatsk.a*****
}

Received: 2021-07-01

Accepted: 2021-08-15

DOI: http:/ / doi.org/10.46489/lbsh.2021-1-2-5

\begin{abstract}
Ukraine's forestry has been experiencing systemic political, economic, social, and environmental problems for many years. This article aims to find new ways to balance production, taxation, and forestry investment to ensure sustainable development. We sought answers to three main questions: Does the modern mechanism of state regulation and forestry financing in Ukraine meet sustainability requirements? What changes will the critical problems of forest ecosystems arise in Ukraine in the long run? What are the prospects for the development of investment in forestry in Ukraine? To answer these questions, we conducted exploratory analyses of taxation and investment in forestry management. Then, we developed a multifactorial forecasting model to predict forest ecosystems' restoration state by 2035 . Using the model, we characterized the relationship between ecological and economic factors for reforestation in the border regions of Ukraine. Finally, we analyzed the coefficients of forest capacity, yield and dynamics of afforestation. According to the results, we proposed: 1) to separate the functions of standard-setting and forest inventory from the function of forest land management; 2) to separate the function of economic activity and control over the implementation of forestry development plans; 3) to stimulate public control and increase effective monitoring of anthropogenic load, forest use and rehabilitation; 4) to improve the organizational and institutional management mechanism as a component of forest production which is the key to improving the forestry sustainability.
\end{abstract}

Keywords: sustainable forestry, forestry management, forestry production, taxation, investments

\footnotetext{
* Orest Furdychko, Doctor of Economics, Doctor of Agrarian Sciences, Professor, Academician of NAAS of Ukraine, chief researcher, department of landscape protection, biodiversity conservation and nature protection, Institute of Agroecology and Environment management of NAAS, 12 Metrological Str., 03143 Kyiv, Ukraine, ORCID: https://orcid.org/0000$\underline{0002-1108-7733}$
}

** Oksana Drebot, Doctor of Economics, Professor, Academician of NAAS of Ukraine, Director of Institute of Agroecology and Environment management of NAAS, 12 Metrological Str., 03143 Kyiv, Ukraine, ORCID: https://orcid.org/0000-0003-2681-1074

*** Oleg Yaremko, PhD in Economics, Ternopil Oblast Department of Forestry and Hunting, 5a Bagataya Str., 46008 Ternopil, Ukraine, ORCID: https://orcid.org/0000-0003-4619-0527

**** Volodymyr Bondar, PhD in Economics, Institute of Agroecology and Environment management of NAAS, 12 Metrological Str., 03143 Kyiv, Ukraine, ORCID: https://orcid.org/0000-0002-1531-3208

***** Mariya Vysochanska, PhD in Economics, Deputy Director for Research and Innovation, Institute of Agroecology and Environment management of NAAS, 12 Metrological Str., 03143 Kyiv, Ukraine, e-mail: mariya_vysochanska@,ukr.net (corresponding author), ORCID: https://orcid.org/0000-0003-2116-9991

****** Liudmyla Sakharnatska, PhD in Economics, Deputy Dean for Educational Work of the Faculty of Economics, Uzhgorod National University, Universytets'ka St, 14, 88000 Uzhhorod, Ukraine, ORCID: https://orcid.org/0000-0002$\underline{5863-4917}$ 
Law, Business \& Sustainability Herald

\section{INTRODUCTION}

One of the Sustainable development goals is to ensure sustainable forests management (United Nations, 2015). This goal concerns biodiversity and the ability of governments to ensure effective policies, particularly in the area of sustainable forestry (Sobkowiak, M., Cuckston, T., \& Thomson, I., 2020).

Today in the forest sector in most regions of Ukraine, the state of forest ecosystems does not meet environmental and economic standards. Therefore, the balanced use of forest resources requires a forest management organizational and institutional system, which involves the market transformation of the forest industry. Under such conditions, for the development of a market economy at the stage of its formation, it is necessary to increase the efficiency of forest ecosystems, improve the quality of forest products, the competitiveness of domestic timber producers, increase revenues from the market of forest products, replenish the State and local budgets for development forest and other sectors of the economy.

Every year both the initiative and the support of the state for forestry production decrease, but the tax burden increases, the number of working capital decreases, the price of forest products decreases, credit conditions become inaccessible to most enterprises. Every year both the initiative and the support of the state for forestry production decrease, but the tax burden increases, the number of working capital decreases, the price of forest products decreases, credit conditions become inaccessible to most enterprises. Erler, J. (1997) rightly noted that processes in forestry are usually not sustainable, for their assessment should be considered in addition to economic factors, environmental, social and ergonomic "compatibility". Similarly, Johansson, J. (2018) emphasized the growing demand for interdisciplinary research on sustainable forestry from the standpoint of social sciences, natural resources policy and practical management. Rout, S. (2010) substantiated the institutional approach in the study of forest management but, at the same time, stressed that institutions alone are not always sufficient to achieve sustainable results. Finally, we agree with Burt, G., Mackay, D., \& Mendibil, K. (2021), who
2021 | Volume 1 | Issue 2 emphasized: "Land, forest and forestry policies continue to evolve and economic, social and environmental challenges are emerging in response and opportunities".

The problems as mentioned above provides the necessity of ensuring a balance of both forestry and forestry production with the use of economic, ecological, social and legal components in market conditions:

- the economic component aims to assess the financial and economic potential of forestry enterprises; it has to reflect a systems approach if we pay attention to the essence of effective management. The structure of this approach should include such elements as mission, objectives, evaluation criteria of the objectives within its target block. In the context of the functional block, it should include planning and organization of activities, accounting and control of achieved results;

- the ecological component aims at increasing the ecological potential of forest ecosystems; increasing their resistance to negative natural influences and technogenic load; introduction of a fee-based forest use instrument, which will be based on normative legal acts;

- the social component aims at maintaining the infrastructure in the settlements located in the wooded area; consideration of the social consequences of forest planning and management process;

- the legal component aims at improving environmental legislation and environmental standards in the process of economic reform.

This paper aims to clarify the links between sustainable forest management, taxation, investment, and institutional transformation.

\subsection{Literature Review}

The issue of sustainable forestry is interdisciplinary and has a broad background. Gillespie A. J. R. (2017) points out that forestry is an interdisciplinary industry that combines environmental, economic and social dimensions. The science of sustainable forestry has been developing since the mid-1960s in parallel with the anthropocentrism establishing and the sustainable development emergence (Brown, P., Pröbstl-Haider, U., \& Koch, N. E., 2016). Sahide, M. A. K., et al. (2020) 
Law, Business \& Sustainability Herald emphasized that governments worldwide promote social forests as part of their stated commitment to sustainable development and social justice.

However, Uibrig, H., Hilbrich, A., \& Hutter, G. (2014), studying the current forest management practice against the background of the broad problem of rural land management, noted the spread of a technocratic approach the presence of concomitant problems of sustainable development. Insufficient orientation of forestry on the principles of sustainability has been known since the 90s. In 1993, Saxena, K.G., Rao, K.S., \& Purohit, A.N. noted gaps in sustainable forest development standards related to the opposition of economic and environmental interests (Saxena, K.G., Rao, K.S., \& Purohit, A.N., 1993). Wood, P. J. (1996) also stressed the importance of institutional transformations to disseminate good forest management standards for a particular country. Over time, the idea of sustainable forestry gained momentum, and already in 2008, Wintle, B.A., \& Lindenmayer, D.B. emphasized that more than 200 million hectares of forest in the world are certified as harvested in compliance with the principles of sustainability (Wintle, B.A., \& Lindenmayer, D.B., 2008).

The idea of sustainable forestry is now quite popular. Douglas Brodie, J. et al. (2016) explain this idea as "forest management to meet society's current needs for forest resources... without compromising their accessibility to future generations". Boyle, J. R., et al. (2016) share the same view and emphasize the importance of creating and maintaining sustainable forests and developing recommendations to overcome uncertainty about sustainable forestry.

Evaluation and monitoring of sustainable forest management policy are necessary conditions for long-term conservation and sustainable development of forest ecosystems and resources Montgolfier, J. de. (1999). At the same time, Vierikko, K. et al. (2010) emphasized that the selection of indicators assessing forestry's sustainability always depends on the socio-cultural context and biogeographical factors.

Cooperation between the state, organizations and local communities is vital for
2021 | Volume 1 | Issue 2 sustainable forest management (Pokharel, R. K., et al., 2015). Johansson, J. (2018) noted that achieving sustainable development in forest management systems depends on the state's initiation of cooperation processes and various voluntary initiatives.

The financial analysis of forestry in Ukraine from a sustainable approach was carried out by Ievdokymov, V. et al. (2021). However, their conclusions apply to a greater extent to forestry enterprises. Unfortunately, researchers of financial aspects of forest management are often abstracted from issues of sustainable development.

Fiscal policy towards forestry should be dynamic, responsive to market and technological changes (Hansen, C.P., \& Lund, J.F. (2018). Lund, J.F., et al. (2014) explored the issues of beneficiaries of forest taxation and some social aspects Chhetri, B.B.K., Lund, J.F., $\&$ Nielsen, Ø.J. are insignificant compared to the personal benefit of households, which showed limited potential for redistribution of benefits within the current taxation system.

In the example of Western Australia, Nery, T. et al. (2019) studied the transformation of approaches to investment in forestry and the impact of tax benefits on the implementation of development policies. West, T. A. P., et al. (2021) emphasized the riskiness of investing in forestry and justified ways to reduce risks by diversifying forestry regimes.

Hardaker, A. (2018) justified the significant role of government support for forestry investment subsidies due to the weak influence of markets on the creation of new forests. Ludwig, A. et al. (2021) focused on the link between public policy, social innovation and investment to address social issues related to forestry.

For forest management in market conditions, in addition to reliable information on the availability and status of use of forest ecosystem components, it is necessary to have a system of assessment indicators that would characterize the level of financial regulation and take into account destructive ecological and economic changes in the forest sector.

We ask three main research questions that we will try to solve in this paper: 
Law, Business \& Sustainability Herald

$\mathrm{RQ}_{1}$ : Does the modern mechanism of state regulation and financing of forestry in Ukraine meet sustainability requirements?

$\mathrm{RQ}_{2}$ : What changes will the critical problems of forest ecosystems arise in Ukraine in the long run?

$\mathrm{RQ}_{3}$ : What are the prospects for the development of investment in forestry in Ukraine?

\section{METHODS}

The theoretical basis of the research consists of fundamental provisions of economic theory, system theory, the economics of natural resource use and environmental protection. In addition, we took into account the works of domestic and foreign scientists on environmental, economic mechanisms for managing forest products based on market economy protection.

First, we investigated the structure of forestry financing in Ukraine. Second, we conducted exploratory analyzes of taxation and investment in forestry management. We determined the tax burden on the enterprises of Regional Forest and Hunting Departments of Ukraine on forestry land with open data. We have described the legal framework for state regulation and financing of forestry in Ukraine. Further, we developed a multifactorial forecasting model to predict the state of forest ecosystems restoration by 2035 . Using this model, based on data from the State Statistics Service of Ukraine, we characterized the relationship between ecological and economic factors for reforestation in the border regions of Ukraine. Finally, to assess the prospects for investment in forestry in Ukraine and analyzed
2021 | Volume 1 | Issue 2

the coefficients of forest capacity of forest products and forest yield of forest products and dynamics of afforestation cost coefficients and cost-effectiveness of forest fire protection.

Conducting the research, we used the following research methods:

- an economic and statistical method (the processing of statistical data in assessing the quantitative dependence of various phenomena and the production of forest products)

- methods of correlation and regression analysis (the study of the impact of forestry activities)

- the mathematical modelling (the establishment of the optimal production and industry structure of forest enterprises)

- the abstract and logical method (the theoretical generalizations and formation of conclusions)

\section{RESULTS}

The high efficiency of forestry management is to ensure profitability in using all resources and valuable properties of forest ecosystems. However, effective management of this process is impossible without fiscal policy as a means of financial regulation of the economy, including forestry, which is carried out through economic levers (taxes and public expenditures), i. e. through their transformation and effective use (Furdychko O.I. et al. 2019).

As we see from Table 1, a part of the payment of taxes is charged for the particular use of forest resources to the State Budget from 2010 to 2019. Therefore, every year it tends to increase by 253.3 million UAH. 


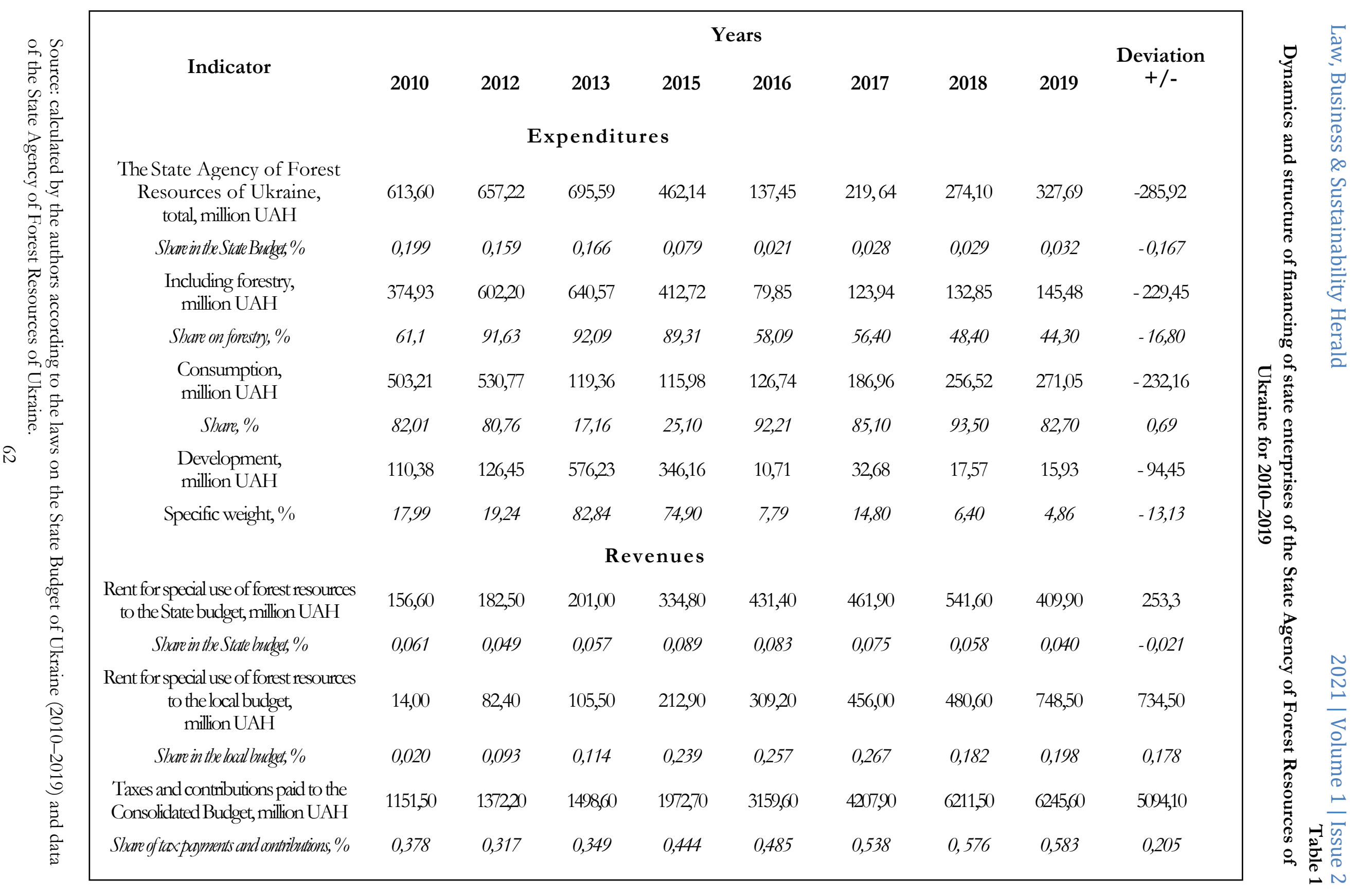


Law, Business \& Sustainability Herald

The rent for the special use of forest resources has rapidly increased by 734.5 million UAH to the local budget compared to 2010. Likewise, the payment of taxes and contributions has increased by 5,094.1 million UAH to the Consolidated Budget. Thus, all the indicators have a positive trend of increasing revenues to the State and Consolidated Budgets; this made it possible to identify revenues and expenditures during the study period. Nevertheless, the most significant of them, represented in Table 1, is the
2021 | Volume 1 | Issue 2 development and management of forestry and taxes, which the financial and social position of economic entities of the State Forest Agency of Ukraine depends on.

According to the analysis, it is necessary to consider aspects of the impact on production, namely: climatic, weather and relief ones. Therefore, taxes and fees should be correlated for forest management so that the more unfavourable the climatic conditions, the lower the tax burden (Figure 1).

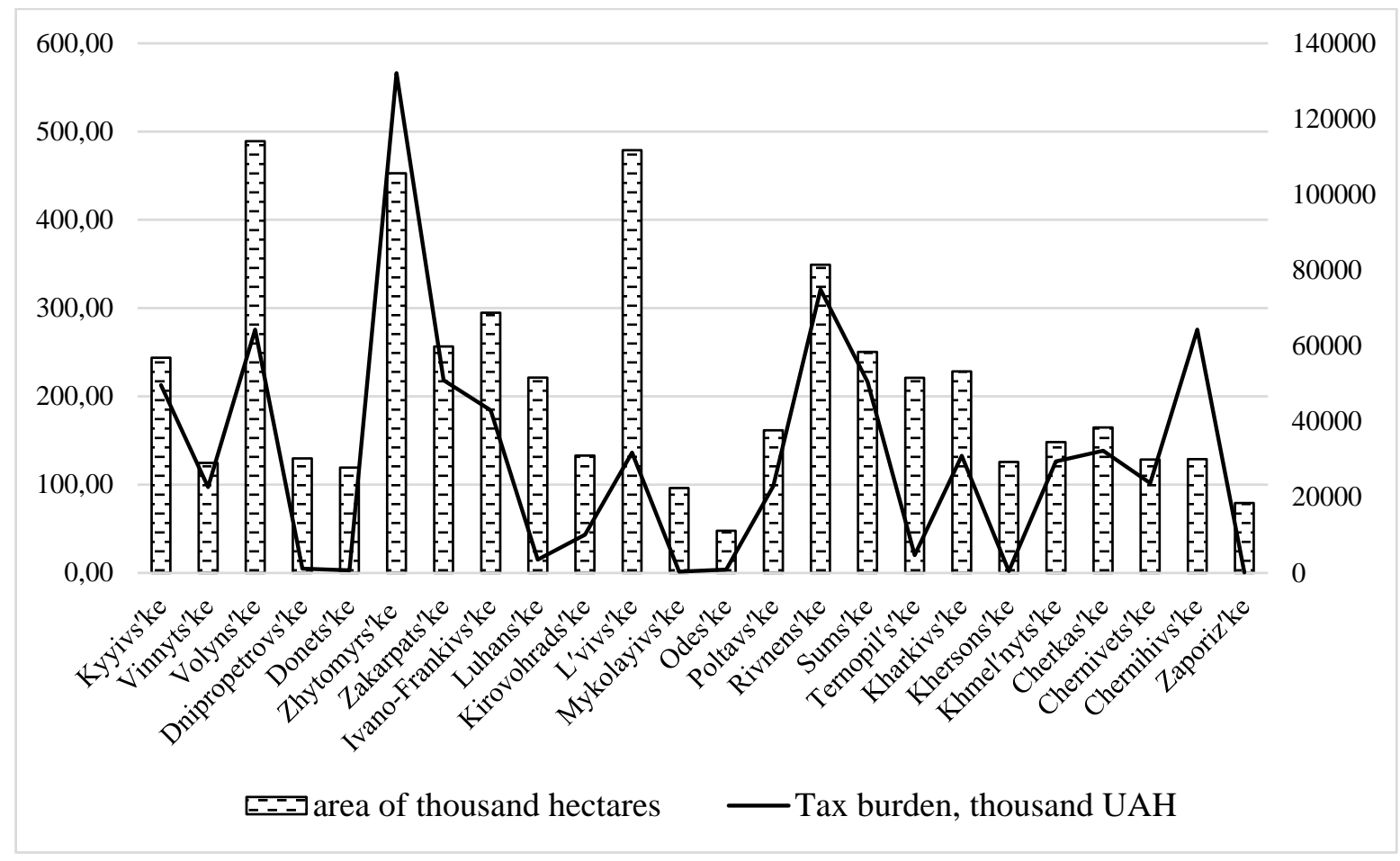

Figure 1. Dynamics of the tax burden of the enterprises of Regional Forest and Hunting Departments of Ukraine on forestry land for 2019

Source: calculated by the authors.

The central part of the taxes of the forestry enterprise is the only social contribution, which is the lion's share of budget revenues not only in Ukraine but also in the Steppe, ForestSteppe, Polissya and Carpathian areas. The rent for the particular use of forest resources is on average $29.8 \%$ for Ukraine; the value-added tax is $20.6 \%$; the corporate income tax is $6.3 \%$; personal income tax is $15.4 \%$. A particular part of the tax is on salaries, which companies pay for full-time employees. On the other hand, such a tax as rent for the special use of forest resources stimulates the efficient, rational, and environmentally balanced use of forest resources. Since 2015 there have been positive changes when the State Budget of Ukraine received all revenues from forestry enterprises. It is a change in the regional direction to centralized funds (Dulik, T.O. and Aleksandriuk, T.Yu. 2016).

According to M.V. Rymar and H.Ya. Il'nyts'ka-Hykavchuk, one of the main reasons for the irrational use of forest resources is the imperfection of the financial mechanism, the lack of investment in reforestation and other environmentally oriented measures. Therefore, as forestry carries out environmental activities and forest resources produce positive internal and external effects, stimulating forest management should be included to provide the 
Law, Business \& Sustainability Herald industry with the necessary financial resources as part of the financial mechanism (Il'nyts'kaHykavchuk, H.Ya. and Rymar, M.V. 2006).

Measures that increase productivity and improve the quality of forests, their protection, conservation, and reproduction are financed from the State Budget and the resources of enterprises, institutions, and organizations. According to Yu.V. Volynchuk and I.V. Bakalejko, an essential element of increasing financial flows to forestry enterprises is the establishment of a regional fund for reproduction, protection and conservation of forests, which can simplify the movement of financial flows in some way following their purpose (Volynchuk, Yu. V. and Bakalejko I.V. 2014).

The primary sources of financing for forestry development are State and local forest users' budgets and other sources, including international organizations and foreign investors. According to article 98 of The Forest Code of Ukraine (The Forest Code of Ukraine, 1994), expenditures on increasing productivity, improving the quality of forests, their reproduction and protection are financed from the State Budget and the own resources of enterprises, institutions and organizations of forestry and forest production. Expenditures on increasing productivity and improving the quality of public and communal forests, their protection, conservation and reproduction are financed through the earmarking of funds from the State and local budgets to implement State and regional (local) forestry programmes. Today, attracting investments has been minimal, as the state has not created appropriate conditions for the formation of
2021 | Volume 1 | Issue 2

institutional support for attracting investments of foreign governments, domestic financial credit, and business structures.

We have selected ecological and economic indicators such as investments in the rational use of natural resources, environmental tax, gross regional product, restoration of forest ecosystems to calculate the forecast multifactor model, which provides for the relationship between the ecological and economic system of forestry development (Table 2). The forecast model makes it possible to assess the impact of investment on the rational use of natural resources to restore forest ecosystems. A multifactorial forecasting model was built based on statistical indicators to determine the correlation, which predicts the state of restoration of forest ecosystems by 2035 .

As shown in Table 2, the investments in the rational use of natural resources (thousand USD) increased in 2017 compared to 2000 by $45.3 \%$, the environmental tax increased by $65.6 \%$.

There is a high correlation between the proposed criteria and the efficiency of forest reproduction, which depends on several factors. Firstly, the time dependence: a forest has a natural reproduction property in the absence of external factors; secondly, the forest reproduction also depends on the investment in natural resource use, the environmental tax and gross regional product (GRP). The high level of correlation makes it possible to assume that the given data can be used to build a predictive model using linear multifactor regression, which characterizes the ecological and economic parameters. As a result, the equation was constructed:

$$
Y=k_{1} \cdot \operatorname{cor}_{1} \cdot T+k_{2} \cdot \operatorname{cor}_{2} \cdot \ln (I)+k_{3} \cdot \operatorname{cor}_{3} \cdot \ln (E)+k_{4} \cdot \operatorname{cor}_{4} \cdot \ln (V)+k_{5}
$$

where $Y-$ reforestation, thousand hectares; $T$ - time in years; $I$ - investments in the rational use of natural resources, thousand USD; E - environmental tax, thousand UAH; $V$ - GRP, thousand UAH; cor $_{1}-$ cor $_{4}-$ correlation coefficients selected by correlation analysis; $k_{1}-k_{4}-$ model weight coefficients; $k_{5}$-compensating component. 


\begin{tabular}{|c|c|c|c|c|c|c|c|c|c|c|c|c|c|}
\hline \multirow{3}{*}{ Criteria } & \multicolumn{12}{|c|}{$\begin{array}{l}\text { Statistical data of Ukraine for the construction of a forecast model for the restoration of forest ecosystems, } \\
\text { thousand hectares }\end{array}$} & \multirow{3}{*}{$\begin{array}{c}\text { Table } 2 \\
\\
2000- \\
2017\end{array}$} \\
\hline & \multicolumn{12}{|c|}{ Years } & \\
\hline & 2000 & 2005 & 2008 & 2009 & 2010 & 2011 & 2012 & 2013 & 2014 & 2015 & 2016 & 2017 & \\
\hline $\begin{array}{l}\text { Investments in } \\
\text { the rational use } \\
\text { of natural } \\
\text { resources, } \\
\text { thousand USD }\end{array}$ & 5587,41 & 7941,59 & 12584,49 & 6562,93 & 4465,02 & 5246,58 & 3160,83 & 4487,45 & 2872,03 & 1516,48 & 910,97 & 1065,17 & 4522,24 \\
\hline $\begin{array}{c}\text { Environmental } \\
\text { tax, thousand } \\
\text { UAH }\end{array}$ & 2634,03 & 5060,36 & 21069,18 & 17484,24 & 17464,83 & 41493,83 & 25297,79 & 39721,58 & 41869,41 & 44556,03 & 60217,91 & 64441,92 & 6807,89 \\
\hline $\begin{array}{l}\text { Reforestation, } \\
\text { thousand } \\
\text { hectares }\end{array}$ & 2336,33 & 3430,16 & 4308,91 & 4019,5 & 3417,5 & 3623,16 & 3830,42 & 3919,58 & 3724,083 & 4122,5 & 4252,42 & 4668,58 & 2332,25 \\
\hline $\begin{array}{l}\text { Gross regional } \\
\text { product, } \\
\text { thousand } \\
\text { UAH }\end{array}$ & 3611,83 & 10081,42 & 20935,58 & 20970,17 & 24508,92 & 30130,75 & 34313,67 & 35489,00 & 40792,25 & 52963,5 & 62958,75 & 67625,50 & 64013,67 \\
\hline
\end{tabular}


The least-squares method (LSM) was used to find the values of the coefficients. This method takes as an estimate of the parameter values that minimize the sum of the squares of the residuals for all observations:

$$
\hat{k}=\arg \min _{\beta} \sum_{i=1}^{n}\left|y_{i}-\beta_{0}-\sum_{j=1}^{k} X_{i j} \beta_{j}\right|^{2},
$$

where $\hat{\mathrm{k}}$ - the vector of estimates of the values of the parameters $\left(k_{1}, k_{2}, \ldots, k_{\mathrm{M}}\right)$; $y_{i}$ - data that are evaluated; $X_{i j}$ - input data (Mayboroda, R. 2007).

$$
Y=237461 \cdot T+840382 \cdot \ln (I)-399929 \cdot \ln (E)-478082
$$

We established the relationship between ecological and economic factors for reforestation in the border regions of Ukraine. Furthermore, we found the correlation of the reforestation indicator (thousand hectares) according to the following indicators: investments in the rational use of natural resources, environmental tax, gross regional product. According to the model estimations, if current forest regeneration trends continue, investments in natural resource management will gradually reduce, and the ecological tax will rise to 88,790 thousand $\mathrm{UAH}$ in 2035. Therefore, the developed model makes it possible to predict the restoration of forests (thousand hectares) in the border regions by 2035 (fig. 3).

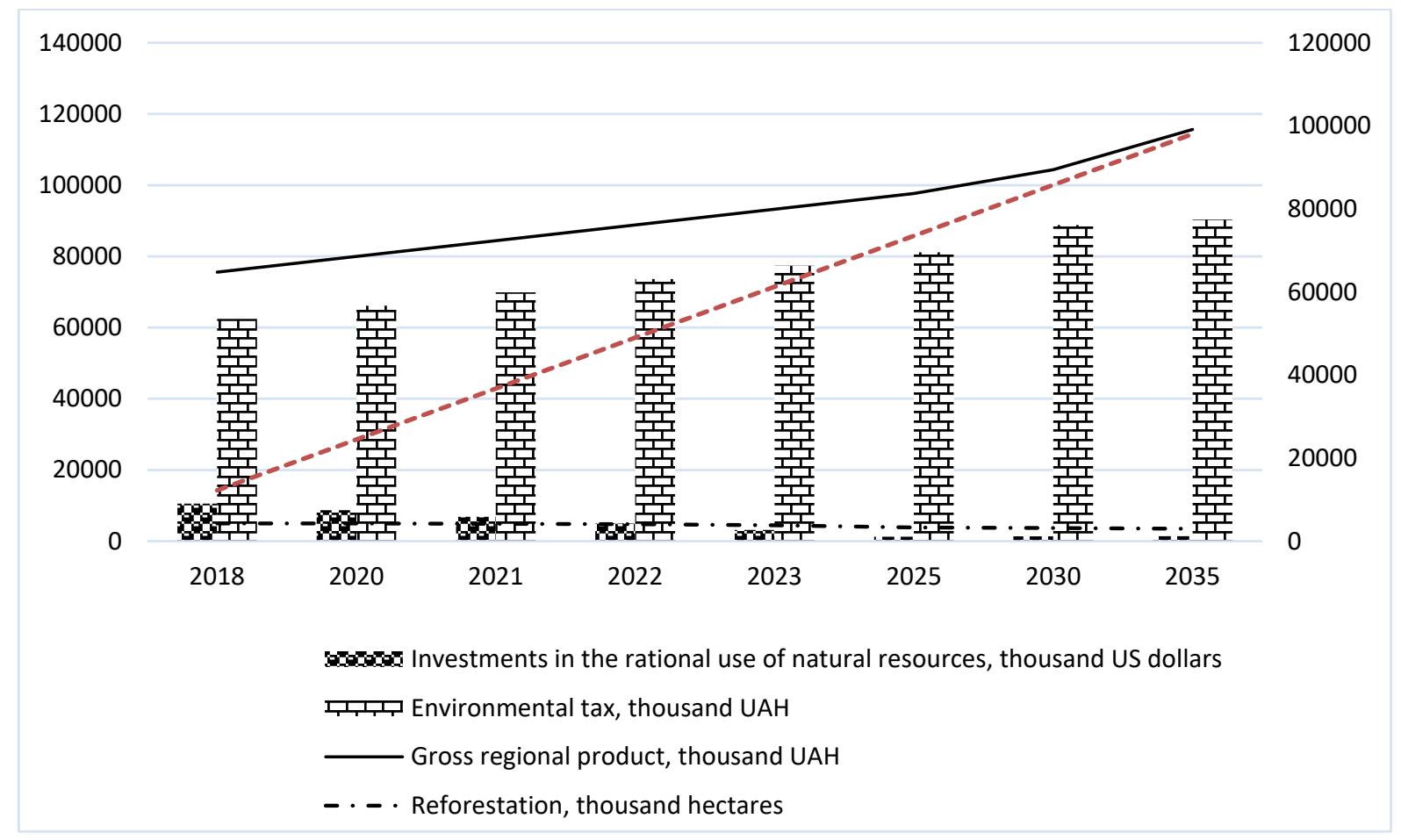

Figure 3. Construction of forecast indicators for the restoration of forest ecosystems

Source: calculated by the authors based on statistical data (Statystychnyj schorichnyk Ukrainy za 2018 rik, 2019 and Official site of the State Statistics Service of Ukraine, 2019). 
When investing, one should consider the integrated impact of investing in the regeneration of forest resource potential. Unlike other sectors of the economy, forestry produces significant positive ecological and social effects, which can significantly exceed the economic effect. Thus the forest industry is significant for society in creating favourable living conditions, the positive impact of forests on the environment, et cetera (Zakon Ukrainy, 2004).

Torosov, A.S.; Zhezhkun, I.M.; Zuiev, Ye.S., (2011), studied the diagnosis of the financial condition of forestry enterprises, focus on the following indicators: liquidity and solvency (total coverage ratio, quick liquidity ratio, absolute liquidity ratio, estimated solvency ratio); financial stability (coefficient of concentration of own capital, coefficient of financial dependence, coefficient of the structure of attracted capital, coefficient of long-term attraction of borrowed funds).

Tkachiv, S.M. and Nykytiuk, P.A., (2017), analyzed the financial and economic indicators of forestry, using quantitative indicators, in particular: the total area of land in use and the area of deforestation; the volume of forestry products; the forest reproduction area; the financial and economic indicators (the volume of sales of forestry products; the funds directed to forestry).

Nestoriak, Yu.Yu. (2009), analyzing the economic efficiency of forestry activities uses the following indicators: the cost of felling; the revenues and labour efficiency in forestry; the effect of forest growing. However, all the mentioned approaches do not consider the specifics of the forestry enterprise and do not determine the qualitative indicators of its activities.

A particular disadvantage is that the available sources of information do not cover statistical data for the calculation or analytical evaluation of forestry and production activities. However, in our opinion, it helps analyze such indicators indicated in Table 3. After all, the analysis of harvesting of forest products involves evaluating the fulfilment of harvesting activities by the forestry enterprise.

Table 3

Systematization of forestry production indicators

\begin{tabular}{|l|l|}
\hline Group of coefficients & Indicator \\
\hline $\begin{array}{l}\text { The coefficient of produced } \\
\text { forest products }\end{array}$ & $\begin{array}{l}\text { Volume of harvested liquid wood, m3. } \\
\text { Actual deforestation, hectare } \\
\text { Tax burden, thousand UAH }\end{array}$ \\
\hline $\begin{array}{l}\text { The coefficient of forest } \\
\text { capacity }\end{array}$ & $\begin{array}{l}\text { Volume of harvested liquid wood, m3. } \\
\text { Actual deforestation, hectare }\end{array}$ \\
\hline $\begin{array}{l}\text { The coefficient of the tree } \\
\text { yield of restoration of forest } \\
\text { plantations }\end{array}$ & $\begin{array}{l}\text { Actual volumes of harvested wood, m3. } \\
\text { Reforestation of permanently managed forests, hectare }\end{array}$ \\
\hline $\begin{array}{l}\text { The coefficient of relative } \\
\text { annual growth of wood }\end{array}$ & $\begin{array}{l}\text { Volume of harvested liquid wood, m3. } \\
\text { Reforestation of permanently managed forests, hectare }\end{array}$ \\
\hline $\begin{array}{l}\text { The coefficient of conservation } \\
\text { of the nature reserve fund }\end{array}$ & $\begin{array}{l}\text { Reforestation of permanently managed forests, hectare } \\
\text { Afforestation on permanent used lands, hectare } \\
\text { Deforestation and reforestation, hectare }\end{array}$ \\
\hline $\begin{array}{l}\text { The of } \\
\text { expenditures on the protection } \\
\text { of forest ecosystems }\end{array}$ & $\begin{array}{l}\text { Volume of forest products (works, services), million UAH } \\
\text { Forest fire protection, hectare }\end{array}$ \\
\hline $\begin{array}{l}\text { The coefficient of } \\
\text { expenditures on afforestation }\end{array}$ & $\begin{array}{l}\text { Afforestation on permanent used lands, million UAH } \\
\text { Volume of forest products (works, services), million UAH }\end{array}$ \\
\hline $\begin{array}{l}\text { The of } \\
\text { reforestation of } \\
\text { plantations }\end{array}$ & $\begin{array}{l}\text { Volume of forest products (works, services), million UAH } \\
\text { Reforestation of permanently managed forests, hectare }\end{array}$ \\
\hline \multicolumn{1}{|c|}{ fourcest formt }
\end{tabular}

Source: formed by the authors. 
Through the correlation analysis, we have researched the extent of correlation between the indicators of forest capacity and forest yield of forest products using a linear graph. As a result, the share of variation in forest capacity tends to increase. The equation of this linear trend has the form $y=0,9248 x-1828$. The reliability of the approximation is $\mathrm{R}^{2}=0.546$ (fig. 4).

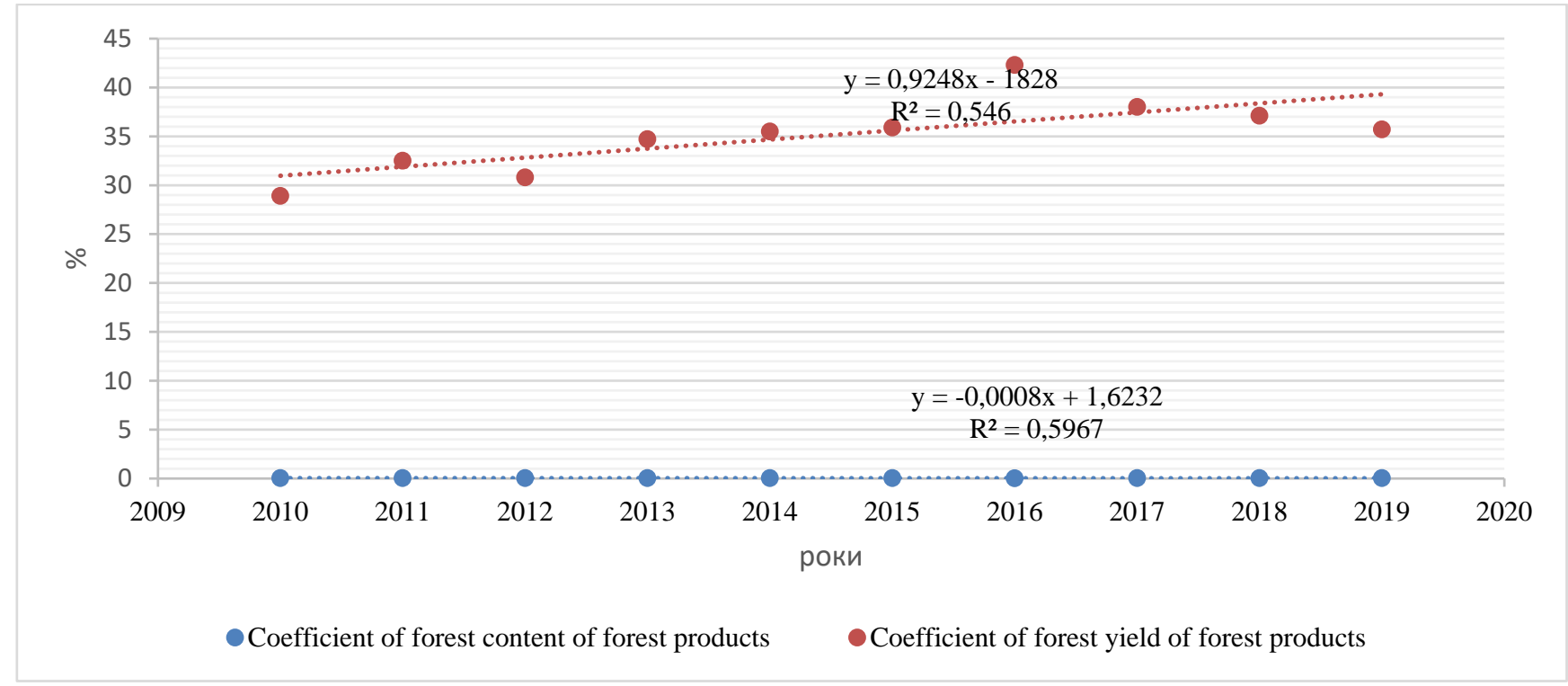

Figure 4. Dynamics of coefficients of forest capacity of forest products and forest yield of forest products

Source: formed by the authors.

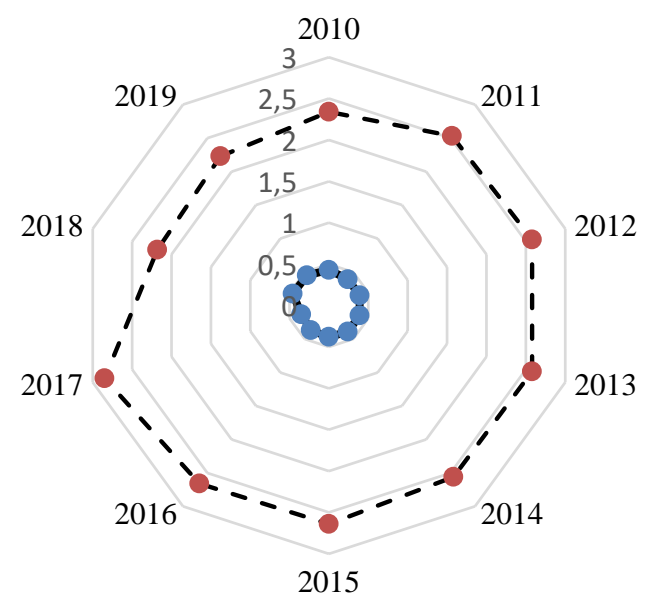

- Coefficient of tree capacity of restoration and planting

- - Coefficient of recovery of trees and plantings

Figure 5. Dynamics of coefficients of forest capacity and produced forest products

Source: formed by the authors.

Figure 6 shows that the highest costs are for forest fire protection and the costs of afforestation tend to decrease every year. Thus, the rational ratio of unproductive costs to measures to minimize was the costs of forest protection from fires, i. e. $1 \mathrm{UAH}$ of funds invested in forest protection from fires is 0.55 UAH of lost forest from fires. 


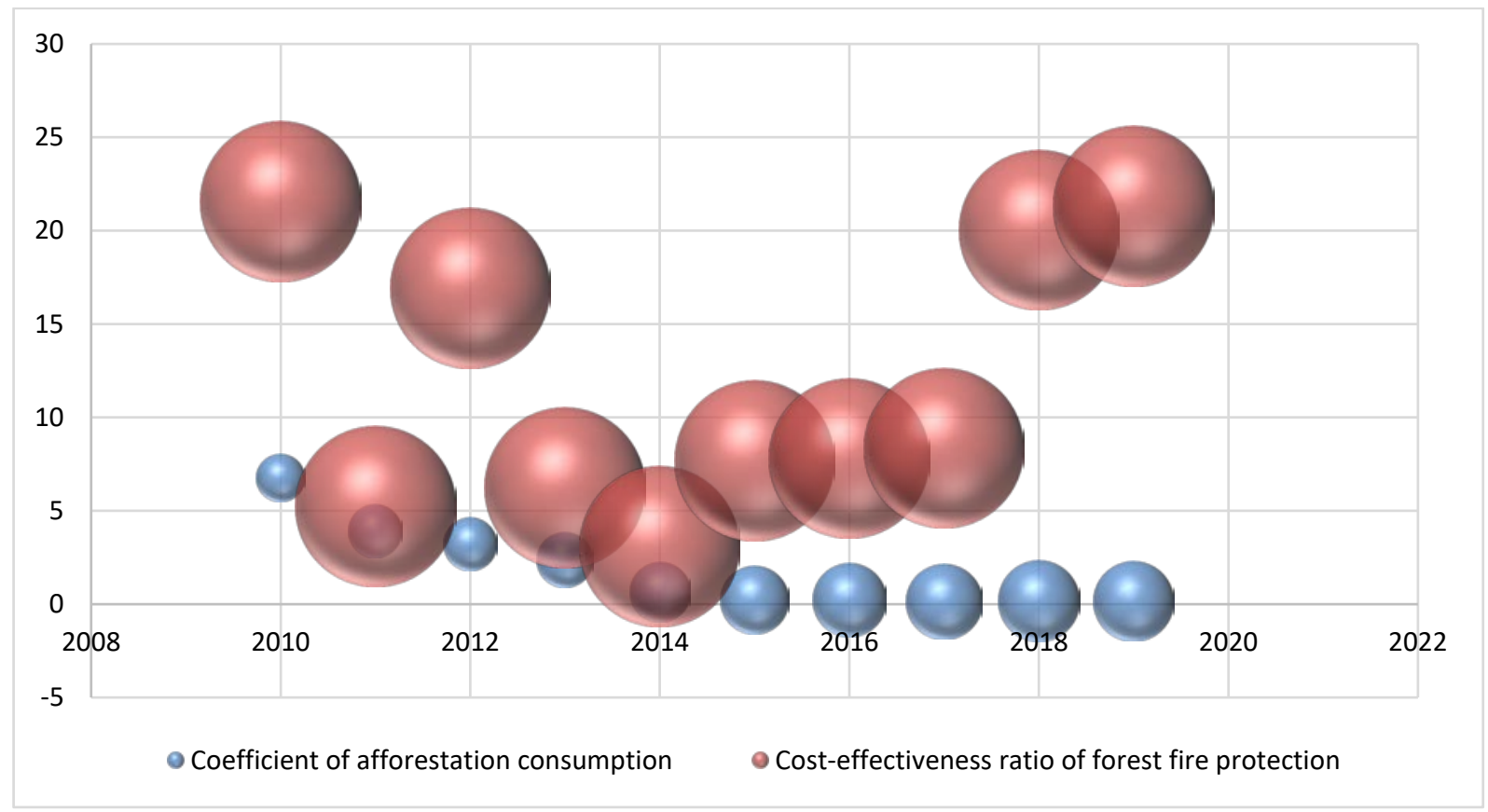

Figure 6. Dynamics of afforestation cost coefficients and cost-effectiveness of forest fire protection Source: formed by the authors.

Calculation of the coefficients of analytical indicators allows assessing the effectiveness of investments in forestry, planting, fighting fires and illegal logging.

It is possible to assess the quality of such measures in correlation with the volume of harvested liquid wood and other types of forestry products, which is a robust analytical basis for assessing the effectiveness of the forestry enterprise.

For a detailed description of the dynamics of the structure of indicators of the volume of harvested liquid wood, the actual felling of wood and the tax burden, polynomial functions of the second-order were obtained (Fig. 7).

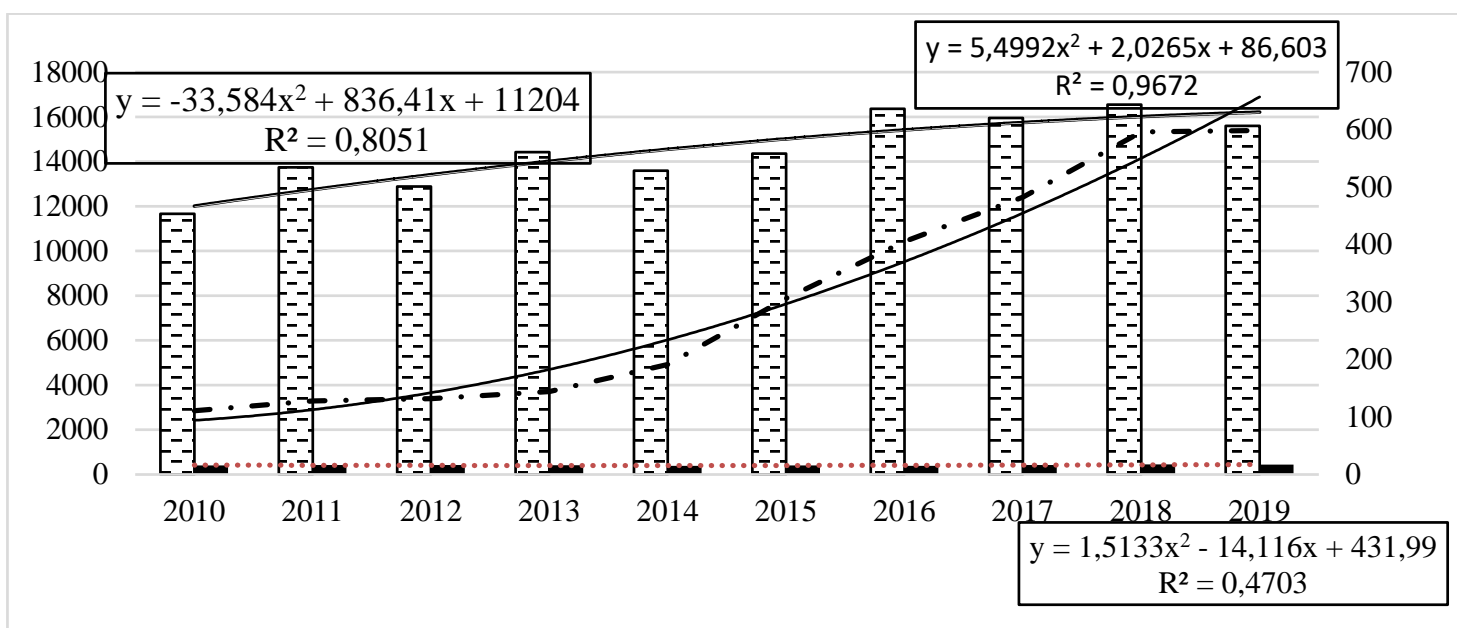

\footnotetext{
$=-3$ Volume of harvested liquid wood, cubic meters. m

- Actual deforestation, hectaresa

- - - Tax burden, thousand UAH
}

Figure 7. Dynamics of coefficients of the produced forest products

Source: formed by the authors on the basis of statistical data and data of the State Agency of Forest Resources of Ukraine. 
Ecological and economic content of the obtained result is as follows: in 2019, the tax burden increased by $\mathbf{1 3 . 0 2 4 5}$ (thousand UAH).
The average value is determined by the formula:

$$
\begin{gathered}
\mathrm{Y}_{1}\left(\mathrm{x}_{\mathrm{mid}}\right)=10,998 x_{\mathrm{mid}}+2,0265 ; \\
x_{\text {mid }}=\frac{10(10+1) / 2}{10}=5,5 \\
Y(5,5)=10,998 * 5,5+2,0265=62,5155(\text { thousand } \mathrm{UAH})
\end{gathered}
$$

The results show that, on average, during the study period, the tax burden increased by

The derived function of the volume of $\mathbf{6 5 . 5 1 5 5}$ thousand UAH per year.

$$
Y_{2}=67,168 x-836,41
$$

After all, for 2019:

$$
\left(x_{\text {mid }}=1\right): Y_{2}=67,168 * 1-836,41=-769,24\left(\mathrm{~m}^{3}\right) .
$$

Ecological and economic essence of the obtained result from the volume of harvested The average value for the analyzed period liquid wood decreased by $769,24 \mathrm{~m}^{3}$.

$$
Y_{2}=67,168 * 5,5-836,41=-466,99\left(\mathrm{~m}^{3}\right) .
$$

On average, during the study period from 2010 to 2019, the volume of harvested liquid wood increased by approximately $466.99 \mathrm{~m} 3$ per year. In order to compare the calculations obtained based on the volume of harvested liquid wood, an assessment of chain growth trends. The calculations of the tax burden for the study period are in fig. 7. As we see from fig. 7 , the rate of liquid wood exceeded tax revenues, including rent for the special use of forest resources, i. e., payment for the use of forest resources, which negatively characterized the filling of the local budget.

We calculated approximation coefficients to show a relatively high quality of the constructed models $(\mathrm{R} 2=0.8664)$ (fig. 8).

For each received function, a derivative is defined that characterizes the acceleration of reproducible processes in forestry. The derivative function of reforestation of permanently owned forests, (y):

$$
Y=172,54 x+1334,4 x
$$

where $(x=1)$ :

$$
Y(1)=172,54 * 1+1334,4=1506,94 \text { (hectares) }
$$




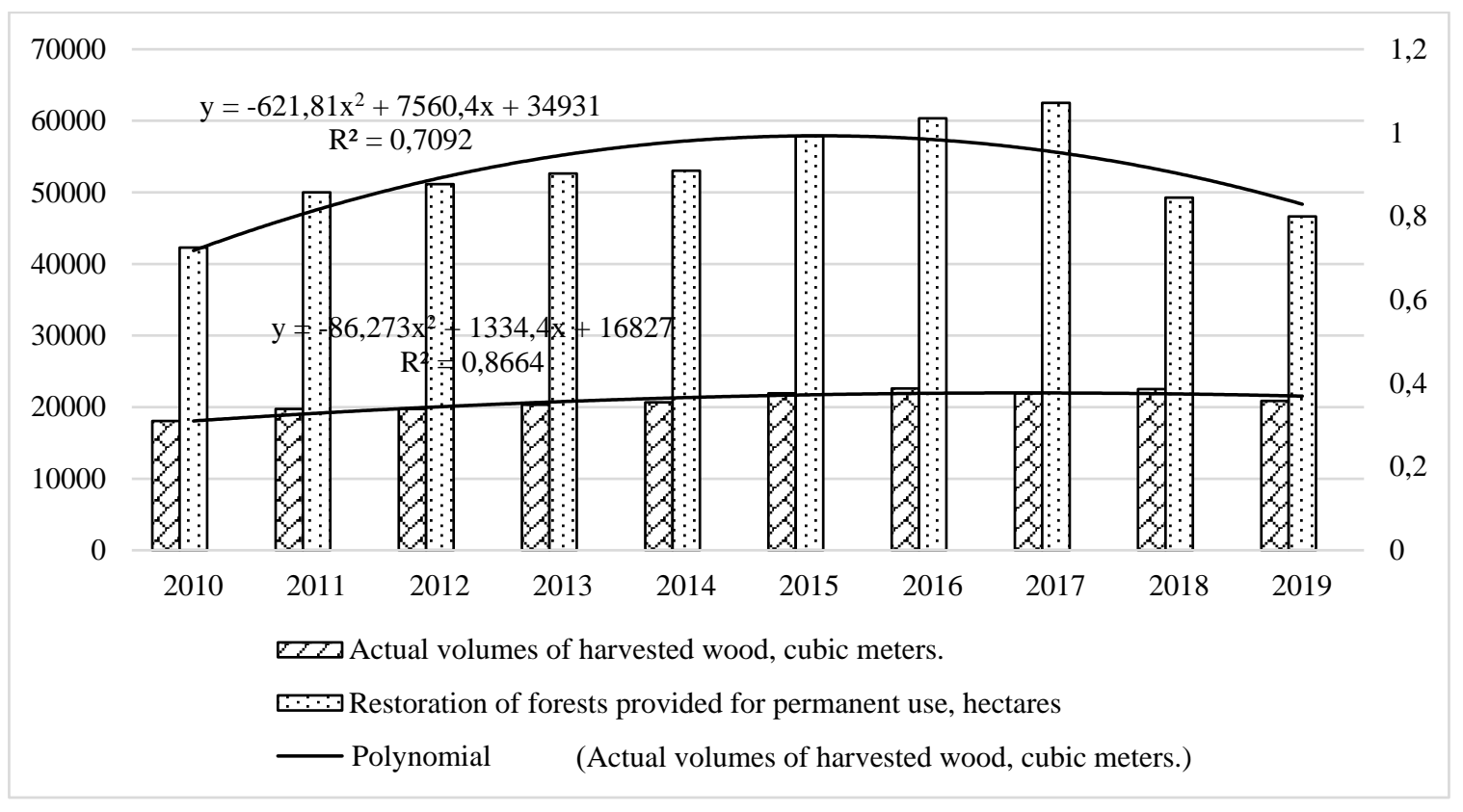

Figure 8. Dynamics of reforestation coefficients

Source: formed by the authors on the basis of statistical data and data of the State Agency of Forest Resources of Ukraine (Statystychnyj schorichnyk Ukrainy za 2018 rik, 2019; Official site of the State Statistics Service of Ukraine, 2019 and Public report of the State Agency of Forest Resources of Ukraine for 2019).

The ecological and economic significance of the obtained result: for the studied period in restoration of forests for permanent use increased by $1,506.94$ hectares.

The formula determines the average value:

$$
\begin{gathered}
Y_{1}\left(\mathrm{x}_{\text {mid }}\right)=172,54 x_{\text {mid }}+1334,4 \\
x_{\text {mid }}=\frac{10(10+1) / 2}{10}=5,5 \\
Y(5,5)=172,54 * 5,5+1334,4=2283,37 \text { (hectares) }
\end{gathered}
$$

The results show that during the study period the tax burden increased on average by 2,283.37 hectares per year.

The derivatives function of the actual volumes of harvested wood $\mathbf{Y}_{2}$ :

$$
Y_{2}=1243,62 x-7560,4
$$

After all, for 2019:

$$
\left(\mathrm{x}_{c e p}=1\right): Y_{2}=1243,62 * 1-7560,4=-6316,78\left(\mathrm{~m}^{3}\right)
$$

The average value for the study period is:

$$
Y_{2}(5.5)=1243,62 * 5,5-7560,4=720,49\left(\mathrm{~m}^{3}\right)
$$

According to the obtained results, from 2010 to 2019, the amount of harvested wood increased by about 2,283.37 hectares per year. In order to compare the calculations made based on the volume of harvested wood, we evaluated the chain growth trends. The calculations of reforestation for the study period are in fig. 8. As shown from fig. 8, the 
rate of timber harvesting exceeded the restoration of permanently managed forests, which negatively characterized the dynamics of reforestation in forestry and forest production.

Using correlation analysis, we have determined that the amount of harvested timber is $75 \%$ of the regeneration of forests for permanent use $\mathrm{R} 2=0.8664$. As we can see, there is a close statistical relationship. The calculated approximation coefficients show the adequacy of the constructed models and their high correlation. The derivatives have been calculated from the above functions, which characterize reforestation efficiency indicators over time and the corresponding growth rates, including forestry development.

\section{DISCUSSION}

The regulation of ecological and economic problems of forestry production is a complex issue that calls for research and a relatively wide range of components of the mechanism of ecologically and economically oriented management of forestry. Therefore, we recommend the government consider the following steps to improve the control process and secure sustainable forestry management: the separation of the functions of setting standards, planning, forest inventory from the function of management of forestry lands; the delineating the management and monitoring of forestry plans, standards and limits; the development of an effective mechanism of preliminary public control (compliance of plans, strategies, programs, et cetera with the interests of the population) and absolute control (control over the activities of state forest enterprises, associations through reports on their activities for a certain period); the introduction of forest certification will provide an opportunity to obtain independent objective control and evaluate the activities of forest enterprises. It will also increase public confidence and allow access to international markets for certified products.

Today the world is more interconnected than ever before. After all, improving access to technology and knowledge is an essential means of exchanging ideas and developing innovative activities in the context of environmental protection (Global Sustainable Development Goals by 2030).
The financial support of the investment environment for the development of the forest sector is an essential component of the relationship between the industry, state, consumers of forest products, and the environment (Antonenko, I.Ya., 2011). The institution of state ownership of forest lands and forest plantations should be recognized as a critical institution in the institutional structure of financial support of the investment environment for the development of the forest sector. This institute is fundamental for forestry activities. However, the current institutional structure for financing the investment environment for sustainable forestry does not meet the new challenges of economic transformation.

There are a large number of systemic contradictions and pitfalls due to the low degree of adaptation to the modern market realities of institutions inherited from the command system of central administration, as well as the weak ability to actively participate in the reproduction process of institutions, resulting from transformational changes (Volynchuk, Yu.V. and Bakalejko, I.V. 2014). The budget financing for the development of the forest sector, both directly and indirectly, has a significant impact on the volume of investment revenues in forestry, as 1) the state directly finances investment in forestry; 2) the state can stimulate private sector investment in forestry through the establishment of tax benefits, grants and soft loans; 3) the state is responsible for implementing the policy of stimulating private investment (Labenko, O.M. and Ivolha, I.H. 2013).

\section{CONCLUSIONS}

Our research has shown that crucial ecological problems are currently associated with specific characteristics, such as:

- the slow implementation of financial mechanisms in the forestry development, as well as the attracting funds to local budgets through the sale of forest products;

- the imperfection of the current environmental legislation;

- the lack of an incentive mechanism for innovation and investment in forests and environmental protection. 
The deliverables include the qualitative assessment of the conformity of the forest management system with the basic design parameters and the interaction between subsystems and elements; the assessing the impact of individual institutional and economic changes on its social, economic and environmental performance. The qualitative assessments describe the completeness and viability of new and modified elements of sustainable forest management.

The study established the relationship between ecological and economic factors for the restoration of forest ecosystems. It examined the degree of correlation of the indicator of restoration of forest ecosystems on such indicators as the investments in the

\section{References}

Antonenko, I.Ya. (2011). Formuvannia rynkovo oriientovanoho finansovoekonomichnoho mekhanizmu rozvytku lisoresursnoi sfery Ukrainy [Formation of a market-oriented financial and economic mechanism for the development of the forest resource sphere of Ukraine]. Agrosvit. 13/14, 712.

Boyle, J. R., Tappeiner, J. C., Waring, R. H., \& Tattersall Smith, C. (2016). Sustainable Forestry: Ecology and Silviculture for Resilient Forests. In Reference Module in Earth Systems and Environmental Sciences (p. B978012409548909761X). Elsevier. https://doi.org/10.1016/B978-0-12-4095489.09761-X

Brown, P., Pröbstl-Haider, U., \& Koch, N. E. (2016). Social and Political Aspects of Sustainable Forestry. In Reference Module in Earth Systems and Environmental Sciences (p. B9780124095489096000). Elsevier. https://doi.org/10.1016/B978-0-12-4095489.09483-5

Burt, G., Mackay, D., \& Mendibil, K. (2021). Overcoming multi-stakeholder fragmented narratives in land use, woodland and forestry policy: The role scenario planning and 'dissociative jolts'. Technological Forecasting and Social Change, 166, 120663. https://doi.org/10.1016/i.techfore.2021.12066 $\underline{3}$

Chhetri, B. B. K., Lund, J. F., \& Nielsen, $\varnothing$. J. (2012). The public finance potential of rational use of natural resources, the environmental tax, gross regional product.

In order to secure sustainable forestry in Ukraine, we propose to 1) separate the functions of standard-setting and forest inventory from the function of forest land management, 2) separate the function of economic activity and control over the implementation of forestry development plans, 3) introduce public control and increase effective monitoring of anthropogenic load, forest use and rehabilitation, 4) improve the organizational and institutional management mechanism as a component of forest production which is the key to improving the forest economy.

community forestry in Nepal. Ecological Economics, 73, 113-121. https://doi.org/10.1016/j.ecolecon.2011.09.02 $\underline{3}$

Douglas Brodie, J., Tattersall (Tat) Smith, C., Tappeiner, J. C., \& Boyle, J. R. (2016). Economic Considerations for Sustainable Forestry. In Reference Module in Earth Systems and Environmental Sciences (p. B9780124095489096000). Elsevier. https://doi.org/10.1016/B978-0-12-4095489.09484-7

Dulik, T.O., \& Aleksandriuk, T.Yu. (2016). Vektory rozvytku suchasnoi fiskal'noi polityky Ukrainy [Vectors of development of modern fiscal policy of Ukraine]. International scientific journal. 2, 107-115.

Erler, J. (1997). Nachhaltgerechte Technikgestaltung in der Forstwirtschaft-Ein Modellansatz. Forstwissenschaftliches Centralblatt, 116(1-6), 105-112. https://doi.org/10.1007/BF02766887

Furdychko, O., Shershun, M., Shkuratov, O., Drebot, O., \& Yaremko, O. (2019). Assessment of the efficiency of sustainable management of forestry Forestry Ideas. Vol. 25. No 2(58). P. 339-350. https://forestryideas.info/issues/issues_Index.php.

Gillespie, A. J. R. (2017). The Evolution of Forestry: An Original Sustainable Systems Science. In Encyclopedia of Sustainable Technologies (pp. 183-190). Elsevier. https://doi.org/10.1016/B978-0-12-409548$\underline{9.10055-7}$ 
Hansen, C. P., \& Lund, J. F. (2018). Forestry taxation for sustainability: Theoretical ideals and empirical realities. Current Opinion in Environmental Sustainability, 32, 23-28. https://doi.org/10.1016/j.cosust.2018.03.002

Hardaker, A. (2018). Is forestry really more profitable than upland farming? A historic and present day farm level economic comparison of upland sheep farming and forestry in the UK. Land Use Policy, 71, 98-120. https://doi.org/10.1016/j.landusepol.2017.11.0 $\underline{32}$

Ievdokymov, V., Grytsyshen, D., Oliinyk, O., Dziubenko, O., \& Yukhymenko-Nazaruk, I. (2021). Financial Potential Analysis of Forestry Enterprises of Ukraine on the Taxonomy Method Basis. Management Systems in Production Engineering, 29(1), 3-13. https://doi.org/10.2478/mspe-2021-0001

Il'nyts'ka-Hykavchuk, H.Ya., \& Rymar, M.V. (2006). Opodatkuvannia v systemi finansovoho zabezpechennia rozvytku lisovoho hospodarstva $\mathrm{v}$ umovakh ievrointehratsii [Taxation in the system of financial security for forestry development in terms of European integration]. Bulletin of National University of $W$ ater and Environmental Engineering. 4, 408-413.

Johansson, J. (2018). Collaborative governance for sustainable forestry in the emerging bio-based economy in Europe. Current Opinion in Environmental Sustainability, 32, 9-16.

https://doi.org/10.1016/j.cosust.2018.01.009

Labenko, O.M., \& Ivolha, I.H. (2013). Finansuvannia proektiv $\mathrm{z}$ vidtvorennia lisu [Financing of forest reproduction projects]. Scientific Bulletin of NULES of Ukraine. (181), 137-144.

Ludvig, A., Sarkki, S., Weiss, G., \& Živojinović, I. (2021). Policy impacts on social innovation in forestry and back: Institutional change as a driver and outcome. Forest Policy and Economics, $122, \quad 102335$. https://doi.org/10.1016/j.forpol.2020.102335

Lund, J. F., Baral, K., Bhandari, N. S., Chhetri, B. B. K., Larsen, H. O., Nielsen, Ø. J., Puri, L., Rutt, R. L., \& Treue, T. (2014). Who benefits from taxation of forest products in Nepal's community forests? Forest Policy and Economics, 38, 119-125. https://doi.org/10.1016/j.forpol.2013.04.010
Mayboroda, R. (2007). Rehresiia: linijni modeli [Regression: linear models]. VPC "Kyiv University".

Montgolfier, J. de. (1999). Indicators for sustainable development in forestry. International Journal of Environment and Pollution, $12(4), \quad 451$. https://doi.org/10.1504/IJEP.1999.002306

Nery, T., Polyakov, M., Sadler, R., \& White, B. (2019). Spatial patterns of boom and bust forestry investment development: A case study from Western Australia. Land Use Policy, 86,

67-77.

https://doi.org/10.1016/j.landusepol.2019.04.0 $\underline{15}$

Nestoriak, Yu.Yu. (2009.) Analiz ekonomichnoi efektyvnosti lisohospodars'koi diial'nosti DP «Putyl's'kyj lishosp» [Analysis of the economic efficiency of forestry activities SE "Putyla forestry"]. Agrosvit. 22, 53-55. http://nbuv.gov.ua/UJRN/agrosvit 200922 $\underline{12}$

Official site of the State Statistics Service of Ukraine. Statystychnyj schorichnyk Ukrainy za 2019 rik [Statistical Yearbook of Ukraine for 2019]. http://www.ukrstat.gov.ua/

Osaulenko, O.G., Eds. (2019). Statystychnyj schorichnyk Ukrainy za 2018 rik [Statistical Yearbook of Ukraine for 2018]. DP Inform.analyst. agency.

Pokharel, R. K., Neupane, P. R., Tiwari, K. R., \& Köhl, M. (2015). Assessing the sustainability in community based forestry: A case from Nepal. Forest Policy and Economics, 58, 75-84.

https://doi.org/10.1016/j.forpol.2014.11.006

Rout, S. (2010). Collective Action for Sustainable Forestry: Institutional Dynamics in Community Management of Forest in Orissa. Social Change, 40(4), 479-502. https://doi.org/10.1177/004908571004000405

Sahide, M. A. K., Fisher, M. R., Erbaugh, J. T., Intarini, D., Dharmiasih, W., Makmur, M., Faturachmat, F., Verheijen, B., \& Maryudi, A. (2020). The boom of social forestry policy and the bust of social forests in Indonesia: Developing and applying an access-exclusion framework to assess policy outcomes. Forest Policy and Economics, 120, 102290. https://doi.org/10.1016/i.forpol.2020.102290

Saxena, K. G., Rao, K. S., \& Purohit, A. N. (1993). Sustainable Forestry-Prospects in 
India. Journal of Sustainable Forestry, 1(2), 6995. https://doi.org/10.1300/J091v01n02 04

Sobkowiak, M., Cuckston, T., \& Thomson, I. (2020). Framing sustainable development challenges: Accounting for SDG-15 in the UK. Accounting, Auditing \& Accountability Journal, 33(7), 1671-1703. https://doi.org/10.1108/AAAJ-01-2019-3810

State Agency of Forest Resources of Ukraine (2019). Public report of the State Agency of Forest Resources of Ukraine for 2019. https://bit.ly/2VGaHil

State Statistics Service of Ukraine. Available online: http://www.ukrstat.gov.ua/ (accessed on 16 July 2021).

Tkachiv, S.M., \& Nykytiuk, P.A. (2017). Analiz finansovo-hospodars'kykh pokaznykiv lisovoho hospodarstva rehionu [Analysis of financial and economic indices of forestry region]. Economy and Society. 9. Available online: https://economyandsociety.in.ua/journals/9 u kr/150.pdf

Torosov, A.S., Zhezhkun, I.M., \& Zuiev, Ye.S. (2011). Diahnostyka finansovoho stanu lisohospodars'koho pidpryiemstva $\mathrm{v}$ systemi antykryzovoho upravlinnia [Diagnostics of financial condition of forestry enterprises in the system of crisis management]. Lisoryj zhurnal. 1, $48-52$.

Uibrig, H., Hilbrich, A., \& Hutter, G. (2014). Land Use Planning for Sustainable Forestry. In J. Pretzsch, D. Darr, H. Uibrig, \& E. Auch (Eds.), Forests and Rural Development (Vol. 9, pp. 291-332). Springer Berlin Heidelberg. https://doi.org/10.1007/978-3-642-41404$\underline{611}$

United Nations. (2015-a). Global Sustainable Development Goals by 2030 . Available online: https://www.ua.undp.org/content/ukraine/uk home/sustainable-development-goals.html

United Nations. (2015-b). Goal 15: Protect, restore and promote sustainable use of terrestrial ecosystems, sustainably manage forests, combat desertification, and halt and reverse land degradation and halt biodiversity loss.

https://unstats.un.org/sdgs/report/2016/goal$15 /$
Verkhovna Rada of Ukraine (1994). The Forestry Code of Ukraine (as amended 27.05.2021).

https://zakon.rada.gov.ua/laws/show/385212/ed20210527\#Text.

Verkhouna Rada of Ukraine. (2004). Zakon Ukrainy "Pro Zahalnoderzhavnu prohramu adaptatsii zakonodavstva Ukrainy do zakonodavstva Yevropeiskoho Soiuzu" [Law of Ukraine "On the National Program of Adaptation of the Legislation of Ukraine to the Legislation of the European Union" (as amended $04.11 .2018)$ https://zakon.rada.gov.ua/laws/show/162915\#Text (accessed on 16 July 2021).

Vierikko, K., Pellikka, J., Hanski, I. K., Myllyviita, T., Niemelä, J., Vehkamäki, S., \& Lindén, H. (2010). Indicators of sustainable forestry: The association between wildlife species and forest structure in Finland. Ecological Indicators, $\quad 10(2), \quad 361-369$. https://doi.org/10.1016/j.ecolind.2009.06.019

Volynchuk, Yu.V., \& Bakalejko, I.V. (2014). Orhanizatsiia finansovykh potokiv u systemi lisohospodars'kykh pidpryiemstv [Organization of financial flows in the system of forestry enterprises]. Economic sciences. Series: Economics and Management. 11, 6-19.

Volynchuk, Yu.V., \& Bakalejko, I.V. (2014). Orhanizatsiia finansovykh potokiv u systemi lisohospodars'kykh pidpryiemstv [Organization of financial flows in the system of forestry enterprises]. Economic sciences. Series: Economics and Management. 11, 6-19.

West, T. A. P., Salekin, S., Melia, N., Wakelin, S. J., Yao, R. T., \& Meason, D. (2021). Diversification of forestry portfolios for climate change and market risk mitigation. Journal of Environmental Management, 289, 112482. https://doi.org/10.1016/j.jenvman.2021.11248 $\underline{2}$

Wintle, B. A., \& Lindenmayer, D. B. (2008). Adaptive risk management for certifiably sustainable forestry. Forest Ecology and Management, 256(6), 1311-1319. https://doi.org/10.1016/i.foreco.2008.06.042

Wood, P. J. (1996). Sustainable forestry and certification in the Commonwealth. The Forestry Chronicle, 72(6), 599-603. https://doi.org/10.5558/tfc72599-6 